\title{
Dutch Curse on Indonesia: Unemployment Caused by Asian Development Bank (ADB) Loan Projects
}

\author{
Mubammad Amir Ingratubun $a^{*}$, Ardika Perdana Fably", Beny Cabyadie, Nefo Indra Nizar", Raden Ratib Rantini \\ ${ }^{a *}$ Regional and Rural Development Planning Department, IPB University, Bogor, West Java, Indonesia.
}

\begin{abstract}
The ADB takes more than five years to disburse the agreed-upon loan funds after the borrower signs the loan agreements, because of the conditionalities attached to such loans, compared with it only taking one day for commercial banks to release any agreed loans. During this five-year period, the funds stay in the bank and gain compounded interest, disfavoring Indonesia. Development studies have mostly overlooked these gains and their impacts. Knowing that ADB loans cause about 3\% of Indonesia's unemployment, we reviewed the delay's impacts during a project's implementation on unemployment involving $325 \mathrm{ADB}$ loan projects, valued at over $\$ 33$ billion, from 1969 to 2017 . We used a non-econometric methodology by adopting the management principles of the project and portfolio. The results show that the ADB's loans at $1 \%$ GDP initially helped Indonesia reduce its unemployment by $30 \%$. However, because of the ADB's standard implementation of five years, along with an extra two-year delay (seven years in total) we observed shorter unemployment reductions by half, but then reversed, increased and tripled joblessness. This is also causing Indonesia to suffer capital losses of $\$ 0.6$ to $\$ 12$ per $\$ 1$ of loan money, which is equivalent to $4.98 \%$ of its GDP because of the delays in the disbursement of the funds. ADB loans have severe negative effects, with over $200 \%$ volatility because of the delays. Fixing this is simple but requires a paradigm shift.
\end{abstract}

Keywords: disbursement delays, unemployment, money creation, negative impact, volatility

JEL Classification: C6, E5, F34 
Gadjah Mada International Journal of Business - May-August, Vol. 23, No. 2, 2021

\section{Introduction}

Indonesia was under the control of a Dutch multinational corporation known as the Dutch East India Company or Vereenigde Oostindische Compagnie (VOC) from the early $17^{\text {th }}$ into the $20^{\text {th }}$ century. The Dutch government nationalized it because of bankruptcy. The VOC nurtured the spread of-among other things-disease, slavery, bureaucracy, globalization, destruction, and exploitation on an unfathomable scale (Shorto, 2013), modern banking, and also planted the seed of a multilateral cooperative bank to develop colonized lands. During this period, the Dutch generated billions of dollars of capital from Indonesia in various forms, including slave trading, and exports to the Netherlands.

The term "Dutch disease" often associated with the natural resource curse, and describes the causal relationship between economic development's growth in one sector and reduction in another. The putative theory is that as national revenues increase, including those gotten from debt capital, foreign aid inflows induce the strengthening of the national currency, gauged by the stability of the exchange rate (Ebrahim-Zadeh, 2003). The theorized impacts would be, among others, increased growth, job creation, revenues, and poverty reduction.

Contrary to the description of the Dutch disease, particularly with capital inflows and the creation of employment, Indonesia suffered from capital outflows, not only during the Dutch colonial period but also from borrowing from the ADB (Fauzi and Ingratubun, 2021). This is because of its infamous disbursement delays that could take, on average, seven years before the borrowed funds enter into the economy of Indonesia, which in most cases are not 100 percent.
A study by the $\mathrm{OECD}^{1}$ (2003) discovered that disbursement delays are one of the five most burdensome donor practices and may cause aid ineffectiveness. Pallage and Robe (2001:10) found that many studies classified disbursement delays (lead and lag) as minor issues. However, Diarra (2011:7) has empirically identified that the "disbursement delays approach" by donors is one of the principal causes of aid volatility. Sogge (2017:36), citing Doucouliagos and Paldam (2015:325) showed that there were many aid-related studies biased toward donors, because of financial sponsorship. To date, notwithstanding that all the aid ineffectiveness studies have been anchored on disbursements, there is almost no reference that shows unequivocally that disbursement delays alone are the primary cause of loan projects ineffectiveness. Currently, to the best of our knowledge, there is no literature on ADB's disbursement delays impacts on Indonesia in general and specifically on unemployment. Let alone from banking theories and practices. Hence, our paper is filling this gap.

We argue that the five year disbursement delays under the ADB's standard loan projects' implementation in Indonesia, as opposed to the full disbursement of $100 \%$ in a year or less, reduces the creation of longterm jobs by about $70 \%$. The remaining $30 \%$ enjoyed beyond year- 5 but also increased the unemployment level by 1.7 times because of the lost job creation opportunities. Delays beyond the five years and the incorporation of compound interest and fees, along with the financial costs of delays under the loanable funds (LF), severely affect growth, which triples unemployment negatively. Disbursement delays induce financial losses as capital out-flights can reach values of over ten times

${ }^{1}$ The Organization for Economic Co-operation and Development 
Ingratubun et al

the loan value (Fauzi and Ingratubun, 2021) under the fractional reserve banking (FRB) theory. If we endogenized these losses in favor of Indonesia, the disbursement delays would hold back growth and increase unemployment. Thus, ADB loans with or without delays have zero impact on increasing growth (Fauzi and Ingratubun, 2021) and reducing unemployment as we present in the result section. But worsen them, hence the Dutch disease going in reverse is inflicting Indonesia, which we term as Dutch Curse.

The following sections discuss aid volatility definitions, ADB implementation delays, and Indonesia's capitals in ADB. The underlying theory of the negative impact of disbursement delays on growth and unemployment, a literature review of aid volatility and returns per U.S. dollar of aid, a brief description of capital endogenization, and three banking theories and practices. Succeeding this, an elaboration on the novel methodology, a discussion of the results, followed by some recommendations. Fauzi and Ingratubun (2021) provide detailed discussions on the impacts of ADB loans on the economic growth of Indonesia, hence this paper briefly touches upon growth. Our paper expounds on unemployment.

\section{Aid Volatility and Unemployment Definition}

Most authors infer that aid volatility is the difference between commitment and disbursement (Pallage and Robe, 2001; Bulír and Haman, 2006; Eifert and Gelb, 2005). Bulír and Lane (2004) refer to aid conditions and Celasun and Walliser (2008) focus on short-

${ }^{2}$ Loans, grants, technical assistance (TAs), and in-kind assistance are categorized as aid (OECD, 2020). https://data.oecd.org/oda/net-oda.htm (25 Aug 2020) falls. All of them harnessed disbursement as the main predictor and almost all used the econometrics approach while the rest had contextual descriptions.

Our paper specifically deals with ADB loans to Indonesia and defines aid volatility as being due to the disbursement delays. We measure this by the difference between 100\% loan disbursements in the first year upon the signing of the loan agreement (LA) versus the planned and/or actual disbursements. We did the analysis using a non-econometric, empirical methodology aided by graphical and numerical explorations.

We used the World Bank's unemployment definition: "the share of the labor force that is without work but available for and seeking employment." Definitions of the labor force and unemployment differ by country.

\section{ADB Disbursement Delays in}

\section{Indonesia}

Development banks, such as the ADB, operate in similar ways to traditional banks (Mazzi, 2013: xxvi). However, unlike borrowing from a commercial bank where the funds or bank credit are disbursed in-full and deposited into the borrower's account upon signing the loan agreement (LA), borrowing from the ADB does not work like this (Figure-1).

The ADB ties its disbursements to certain conditions and controls over the loan account. Kanbur (2000:413-416), a former World Bank staffer, expresses that conditionality, of whatever type, has failed in Africa and they designed it to fail as a systemic imperative to ensure that aid keeps flowing. Conditionality incriminates the actual issue, which is "one of an unbealthy interaction between 


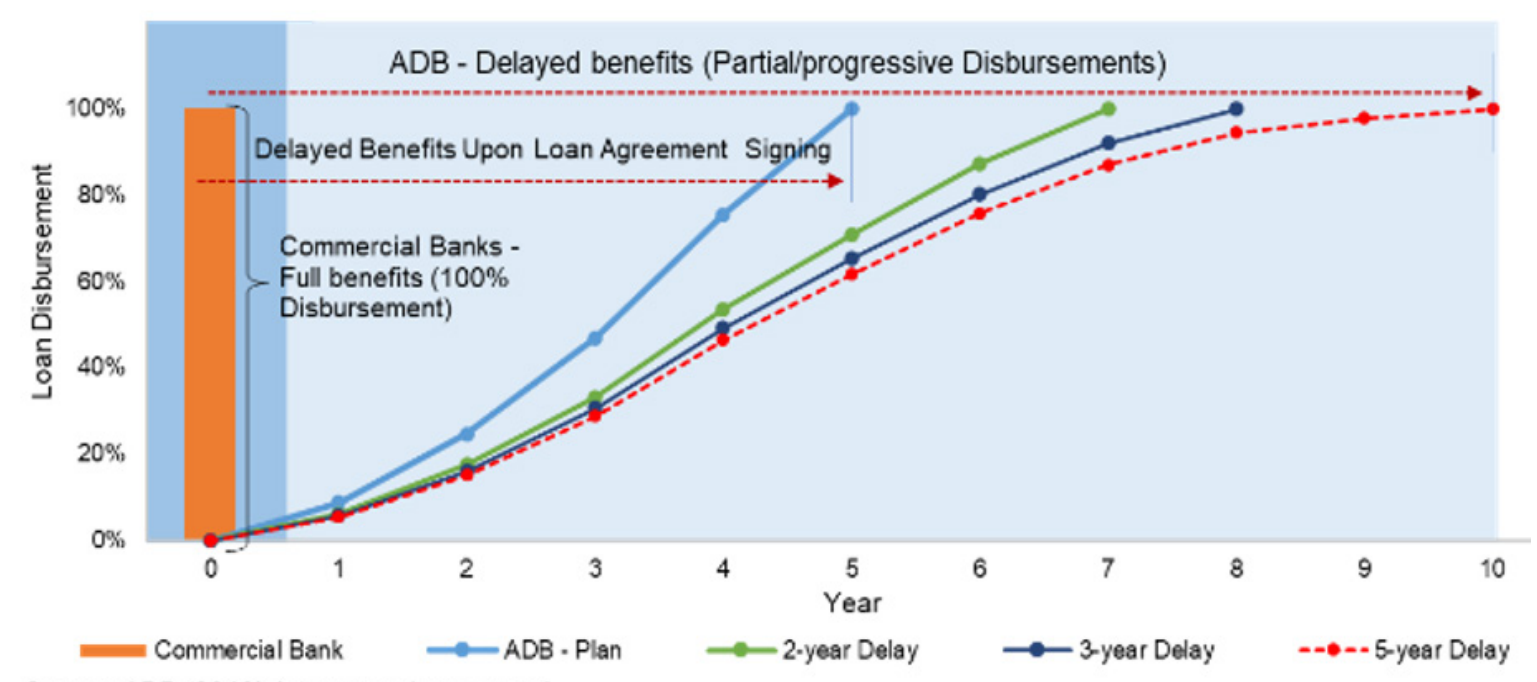

Source: ADB (2010), internet and processed

Note: ADB disbursement S-curve profiles are derived from 1985-2009 data

Figure-1: Loan Disbursements Comparison, Commercial Banks vs ADB

donor and recipient processes which propagate aid dependence but are not so simple as to be characterized as the strength of the donors and the weakness of the recipients." (Kanbur 2000:414.) To date, as shown by Howarth (2017:33), the infliction of conditionality is a nuisance, it is highly controversial, and ineffective.

Essentially the $\mathrm{ADB}$ requires that, upon signing, the borrowers must meet certain LA conditions before the bank will make the first disbursement, and only then will the loan become effective, which signifies the availability of the funds. This is still subject to the submission of a withdrawal application (WA) by the borrower and the formal no-objection (NO) issued by the ADB before disbursing any funds. The process takes time and causes delays. Ensuant disbursements follow the same procedure. The Ministry of Finance of the Republic of Indonesia (MOF-RI, 2020) provided the first disbursements data for ADB loan projects (1969 to 2017, Project No.128327) with a total of US $\$ 37$ billion (Figure-2). Indonesia signed the first ADB loan (No.12) on July 2, 1969 and it took 3.7 years (year four) for it to receive the first disbursement on February 7, 1973.
The average first disbursement time since 1969 is over two years (year three). The standard overall project implementation duration of the ADB is five years (ADB 2018 $\left.\mathrm{APPR}^{3}: 21\right)$, which normally coincides with the grace period. On average, ADB-wide experiences 2.2 years of delays, hence in their year-8 implementation (ADB 2018 APPR: iii). This is consistent with Indonesia's project data. According to ADB President Nakao, about $90 \%$ of ADB loan projects experience two year delays (Witular, 2016). Hence, in our analysis, we use the standard five years with two extra years of delays (hence seven years.).

\section{Indonesian Capitals in $A D B$}

Established in 1966, the ADB, as a quasi-government, required an establishment act, which each of the member countries had to ratify through their national laws. Indonesia enacted Law No.4/1966 accordingly. This ensured that the ADB would have no competition in providing services to Indonesia. Block (1988: 3) expresses that when the gov-

${ }^{3}$ ADB, 2018 Annual Portfolio Performance Report (APPR) 
Ingratubun et al

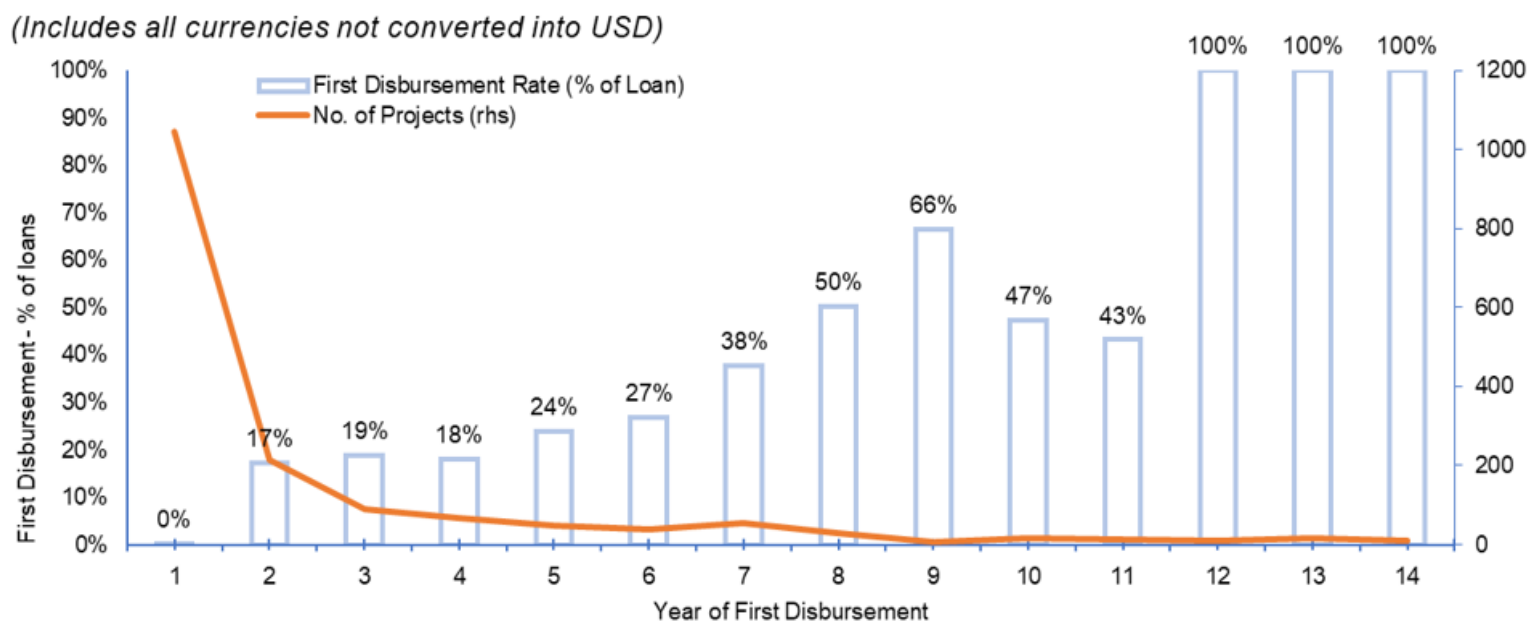

Source: Ministry of Finance, Republic of Indonesia (2020), processed

Figure-2: Indonesia-ADB Loans 'First Disbursement'

ernment gives a legal status to an entity and passes a law that protects it from competitors, it creates unemployment. Block (1988: 2) argues that "[i]n almost every case, government programs are the cause of joblessness" and the free market is better and more efficient at creating employment than politicians and bureaucrats are, as with ADB loans .

Indonesia paid-in (in-cash) plus subscribed capital (in total about $\$ 8$ billion) and guarantees or securities (in-kind) to the ADB, which under banking practices are Promissory Notes (PNs) as per the Bill of Exchange 1882. Thus, they are tradable as securities, can be leveraged as deposits, or used to create money. Each signed LA is a tradable security and bank reserve (Nichols, 1992:11; Werner, 2016; and IMF, Gross and Siebenbrunner, 2019), and adds to Indonesia's securities in the ADB. These are leveraged as 100\% full loan-fund-disbursement collateral. Indonesia has a much larger disbursement capacity of $14 \%$ of GDP, compared with the average ADB loans of $0.415 \%$ of GDP, or equivalent to $0.1 \%$ of GDP disbursement/year. Alternatively, if we use Appendix-A data on average ADB loans over Indonesia's disbursement capacity, assuming the ADB disburses 15\% to $20 \%$ per year, this gives a ratio of $1: 225$ (1:169) meaning Indonesia has a much larger capacity (169 to 225 times per year) than the ADB. Despite this, the ADB insists on controlling, and thus delaying, the disbursement following its interpretation of Article 14 in its charter, and awkwardly Indonesia agrees. The Netherlands is one shareholder and a non-borrowing member of the ADB.

\section{Theory and Hypothesis}

We attempt to answer the question on the extent of ADB's loans disbursement delays impacts on Indonesia's development particularly on unemployment.

Ibnu Khaldun, in the 14th century predating all Nobel prize winners, warned that when a ruler (government) does not spend money, it causes a shortage of capital. "Now, if the ruler keeps it to bimself [undisbursed], it is lost to the subjects" (Khaldun, 1377:365). He likens the capital, in the form of fund, with water. Thus, similarly, ADB loans, if disbursed into Indonesia, correlate to capital, greens, and fertile soils (Khaldun, 1377). Hence, while the $\mathrm{ADB}$ loan funds remain undisbursed, it is a loss to Indonesia. 


\section{Literature Review}

\section{Aid Volatility, Growth, and Unem- ployment}

The United Nations has expressed that unemployment and underemployment are the major causes of poverty (UN, 2012:3-4). However, there is a scarcity of literature that deals with aid's nexus with unemployment. This is most probably because of the preferred linkages between aid and employment when the literature is discussing growth. In 2009, the IMF identified that the right type of development aid has a positive impact on long-running economic growth (Minoiu and Reddy, 2009:6) ${ }^{4}$. However, their most recent study discovered that there is no robust evidence that aid increases growth (Dreher and Lohmann, 2015:5) and creates jobs. Despite

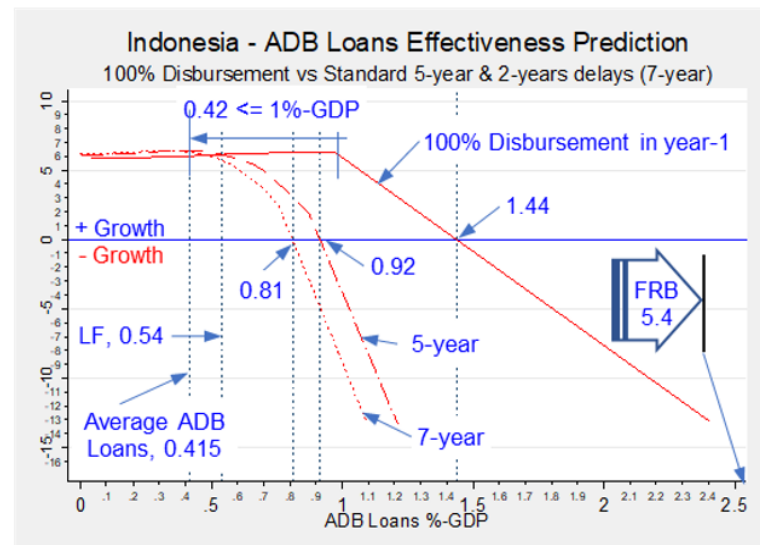

Over the past 40 years, significant evidence has shown that aid volatility has had a severe negative impact on growth, but there is little knowledge about the primary sources (Desai and Kharas, 2010:1) and on their nexus with creating employment; despite the mainstream putative aid theory of growth promotion, job creation, and poverty eradication. Desai and Kharas (2010) identified loan disbursement delays as a source of aid unpredictability, which impairs aid recipients through rising financial costs (see also ADB 2011:26 on cost increases). It slashes investment and reduces welfare, hence it affects growth and employment levels. Kharas (2008:9) exhibits that disbursement volatility has massive negative shocks on growth and national income, similar to those experienced by developed countries during the two world wars and the Great Depression.

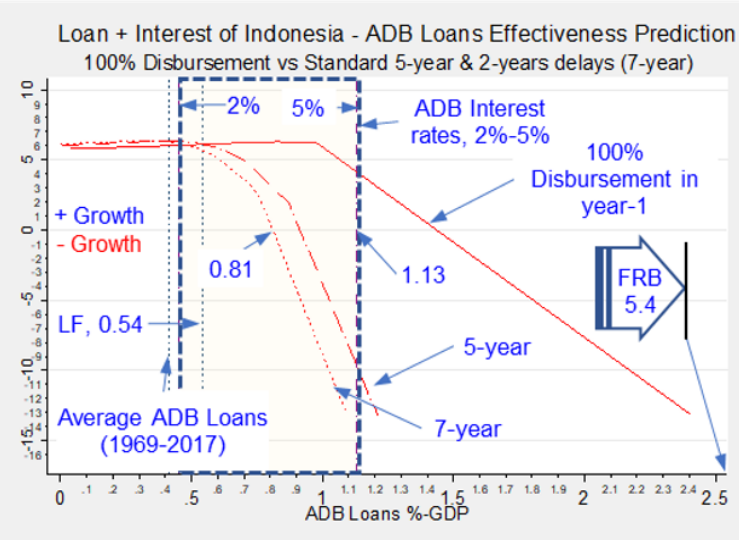

Note: $L F=$ Loanable Fund and FRB = Fractional Reserve Banking. Source: Fauzi and Ingratubun (2021)

Figure-3: ADB Loans disbursement delay and interests impacts on Indonesia's growth

development aid initiatives being established in the 1940s, the linkage between aid's volatility, effectiveness, and growth has long been neglected by scholars (Bulír and Hamann, 2006:4; Diarra, 2011:1).

${ }^{4}$ See McKee et all (2020) footnote 16 for more detailed elaborations on aid promotes or discourages growth at https://www.cgdev.org/sites/default/files/ WP524-McKee-Mitchell-Aid-Effectiveness.pdf (14 Dec 2020)
Fauzi and Ingratubun (2021) discovered that $\mathrm{ADB}$ loans have had very little or no positive impact on the economic growth of Indonesia, but have caused negative growth (Figure-3) or acted as a hand-brake on accelerating growth. They show that over 10 times Indonesia's capital, per one dollar loan fund being delayed, suffer capital flight. These are benefiting the economic growth of the coun- 
tries where the ADB keeps Indonesia's loan funds, while decelerating Indonesia's growth. We translate this as the Dutch curse at work, since, despite the money (or capital) being present, Indonesia cannot use it - but others can-while Indonesia suffers from capital flight.

\section{The Impact of Disbursement Volatility}

Aldashev and Verardi (2012:3-4) show that doubling aid volatility causes a fall in average GDP growth by two-thirds (67\%). Using return per $\$ 1$ aid invested and disbursed by donors as a measure of volatility, this shows a range of $15 \%$ to $2,400 \%$ (Jepma, 1991; Andrews and Wilhelm, 2008; GFI et al., 2015; ANU, 2017; Lotti and Presbitero, 2019; Hickel, 2019; and Fauzi and Ingratubun, 2021). The U.S. Congress (1968a:280) record relating to the 1969 budget appropriation for the ADB registers that "we find that many of the members ... put in $\$ 1$ and get out $\$ 7$ [or 700\%]." For paying interest alone it consumes $0.8 \%$ of GDP and total capital flights are $7.6 \%$ of GDP (Griffiths, 2014) ${ }^{5}$.

\section{Capital Endogenization}

The interest earned on ADB undisbursed loan amounts and fees are profits for the $\mathrm{ADB}$ and/or its private bank, and not accounted for as Indonesia's national income (paradox of profits). For monetizing those gains for the benefit of Indonesia before endogenizing them, we are consistently treating them as a source of capital (Zezza, 2011:15) for Indonesia. Capital endogenization is common in assessing regional economic wealth leakages (Rustiadi et al., 2018) and development's sustainability (Fauzi, 2019).

\footnotetext{
${ }^{5}$ Developing countries lose $\$ 2$ for every $\$ 1$ they earn. https:// www.euractiv.com/section/development-policy/opinion/developing-countries-lose-2-for-every-1-they-earn/?fbclid=IwAR1-sYzJR0cWMFVtBiaBOuSe3Kp3RWqtlW70wG8f8mgJoGYvl7e4qxTItmU (23 Dec 2020)
}

\section{Foundation: Banking Theories,}

\section{Practices and Governance}

Bourguignon and Sundberg (2007); and Edwards (2014) have voiced the need to go beyond econometrics to open a black box of development aid. This is because a plethora of studies, including those into aid volatility, remain inconclusive. Since no cross-country financial transactions (GFI et al., 2015) can occur in the world without engaging with the banking systems, this paper builds its foundation on banking practices, rather than econometrics. As the black box opener, Galbraith (1975:5) expresses that the knowledge of how banks work is essential. He says that " $t]$ he studies of money, above all other fields in econom$i c s$, is the one in which complexity is used to disguise truth or to evade truth, not to reveal it.... Money, in contrast, is equally important to those who have it and those who don't. Both, accordingly, have a concern for understanding it." Hence, the subsequent section opens the black box briefly, by expatiating on the three banking theories identified by Werner $(2014,2016)$.

\section{Financial Intermediation Banking (or Loanable Funds) (LF)}

First, LF is the most dominant theory which holds that banks are merely financial intermediaries. They gather deposits, mostly in cash, from patient savers and lend them out to customers or impatient spenders and charge interest. $\mathrm{ADB}$ appears to practice the $\mathrm{LF}$ as it continuously requests its member countries to replenish its ordinary capital resources.

\section{Money Multiplier or Fractional Re- serve Banking (FRB)}

Second, the FRB theory adopts the idea that banks create money via the expansion 
Gadjah Mada International Journal of Business - May-August, Vol. 23, No. 2, 2021

of multiple deposits by using a fraction of the money in their possession as the basis for generating credit. A bank with $\$ 10$ cash as its entire holding is able to lend out $\$ 100$ (10 times) under the $10 \%$ reserve rule ${ }^{6}$ (Nichols, 1992 (1st ed., 1961:11)). At the time of the ADB's creation in 1966, the $\mathrm{FED}^{7}$ required all banks to maintain a reserve ratio of 4 to 6\% (The Fed, 2020, Footnote 10-13). The Fed nullified this requirement on March 26, 2020 (The Fed, 2020) which means any bank can lend out money with zero reserves (Nichols, 1992:3). As per its 2020 information statement (ADB, 2020:4) ${ }^{8}$, the ADB's lending operation appears to maintain a 4 to $8 \%$ reserve (FRB) ratio. We measured this from the paid-in capital (PIC) in cash ( $\$ 7,372$ million) or other reserves (Table 12, Footnote c:24) over its maximum lending ceiling (MLC) of $\$ 192,547$. This is 1.3 times over its subscribed capital (SC) of $\$ 147,120$. With a 4 to $8 \%$ reserve, the ADB can lend out between 12.5 to 25 times its PIC . Based on this evidence we assumed that the ADB, through its banking governance, is adopting both the FRB and LF. This paper uses these two terms in the analysis.

Werner (2014, 2016), Keen (2014) and Moore (1983), and a growing number of central banks, for example, the Fed (Carpenter and Demiralp, 2010) and the Bank of England (McLeay, et al., 2014), have mathematically, empirically, and practically proven that both LF and FRB theories are untenable, factually incorrect and do not reflect reality, hence they are indefensible.

\footnotetext{
${ }^{6}$ Adopted based on Indonesia, Article 62.b, Law No.23 (1999) on Bank Indonesia.

${ }^{7}$ Federal Reserve Bank, the central bank of the US.

${ }^{8}$ ADB Information Statement 2020. https://www.adb.org/sites/ default/files/institutional-document/417506/information-statement-2020.pdf (25 Aug 2020)
}

\section{Credit Creation (CC)}

Third, CC is the most dominant theory currently practiced around the world, in which banks require neither deposits nor reserves. The Bank of England describes that the money's creation begins when a client signs the LA. They state that "The bank, therefore, creates its funding, deposits, in the act of lending, in a transaction that involves no intermediation whatsoever." (Jakab and Kumhof, 2015: ii). All the banks need for credit money's creation is a signed LA or Promissory Note. This is the oldest banking theory in a modern civilization, based on 5,000 years of practice (Werner, 2016; Hudson, 2018). Werner (2014:14) in the first-ever practical empirical test of 5,000 years of modern banking, observed this in real-time and in an actual bank environment. $\mathrm{A} \mathrm{BBC}^{9} \mathrm{crew}$ filmed the whole process of LA signing until he received the credit money into his bank account. The entire process took 35 minutes in contrast with the fund outlaying by the ADB that take over five years or an average of 7 to 8 years (Figure-1).

\section{Banking Practice Illustrations}

To illustrate the gains from money creation under the three banking theories, this online calculator ${ }^{10}$ helps view those gains. The calculator uses the compounded interest formula $\mathrm{A}=\mathrm{P}(1+\mathrm{r})^{\mathrm{t}}$. We run two scenarios, namely borrow-to-invest (BTI) and borrow-to-project finance with a \$10 annual withdrawal (BTPF), hence an eight year investment. Annual interest (r) uses estimated average ADB loans to Indonesia of $4.727 \%$ and compounded annually. A hypothetical loan (P) of $\$ 100$ under LF and 10\% bank reserve hence, 100/10\% $=\$ 1,000$ money creation under FRB or CC.

\footnotetext{
${ }^{9}$ The British Broadcasting Corporation, https://www.bbc.com/

${ }^{10}$ Savings calculator at https://www.thecalculatorsite.com/finance/ calculators/savings-calculators.php (12 Dec 2020)
} 
For $(t)$, we applied eight years under LF to reflect the average ADB delays and five years for FRB/CC which coincides with the ADB's grace period when loan repayments begin in the sixth year and the beginning of FRB/CC money creation's reduction. We did not calculate the loan principal repayment plus interest to mirror the implementation phase or grace period of the ADB loans. The results show gains (A) of $\$ 44.70$ (BTI) and $\$ 23.48$ (BTPF), hence the gain per $\$ 1$ loan is between $\$ 0.24$ and $\$ 12.60(\$ 2.60+\$ 10)$ or $30 \%$ and $1170 \%$ for LF and FRB, respectively. This includes the newly created money plus compounded interest which is not all in favor of Indonesia, hence a capital flight or loss.

Hence, this means for every one year delay in an $\mathrm{ADB}$ loan funded project it causes the borrower (i.e., Indonesia) to lose between $\$ 0.03$ (\$0.24/8 a year) and $\$ 2.52(\$ 12.60 / 5$ a year) per $\$ 1$ loan or $\$ 0.003$ to $\$ 0.21$ per $\$ 1$ loan/month under LF and FRB correspondingly. In brief, if the ADB does not disburse $100 \%$ of the loan fund in the first year, upon LA signing, it financially costs the borrower between $\$ 0.3$ to $\$ 21$ per $\$ 100$ loan/month under prevailing banking practices. The ADB (2018, footnote a:37) states that avoiding a two-month delay in their project's implementation might increase the net economic benefit by $1 \%$ of their loan portfolio, which is equivalent to $\$ 0.5$ per $\$ 100$ loan. Based on this, we infer that the $\mathrm{ADB}$ is gaining interest through BTPF on undisbursed funds (See also U.S. Congress, 1968a:274).

\section{A Case Study With One Country and One Source of Funding}

As identified by the World Bank (Bourguignon and Sundberg, 2007:316; Aldashev and Verardi 2012:2; Edwards, 2014; and Howarth 2017:41-49), lumping aid and countries together in the analysis have fragile, fragmented, often ambiguous, spurious and inconclusive results. Hudson (2015:66) concluded that the most important predictor of aid volatility is debt, financed by loans. Dreher and Lohmann (2015:5) identified the gap in the literature on aid effectiveness because of the lack of empirical evidence at the country-level. Hence, this paper covers only one country (i.e., Indonesia), and one component of aid, which are ADB loans.

\section{Methods}

\section{Methodology}

Our paper used a novel method identified as development outcomes attribution (DOA) on bank outlays growth on-development results (BOGOR) (Ingratubun, 2020). Our method relied on the triangulation-a principle widely used in geodetic and geo-positioning (e.g., GPS) sciences_of the results which gives a three-dimensional view of the outcomes. DOA-BOGOR applies quantitative attribution by treating a scenario of $100 \%$ loan disbursement upon LA signing ${ }^{11}$ in the first year as the benchmark. We then compared this with a progressive disbursement based on a projected S-curve and integrated money's creation and the compounded interests and fees from undisbursed amounts, using the triangulation of numerical, graphical, and stochastic agent-based modeling (SABM) approaches. The numerical method arranges the data in a time-series and following Figure-4, calculates the impact of delays using $100 \%$ disbursement in the first year as the benchmark. The graphical method involves

\footnotetext{
${ }^{11}$ Keeping in mind that a signed LA is a promissory note and within the same day creates new money and generates gains thereupon.
} 
Gadjah Mada International Journal of Business - May-August, Vol. 23, No. 2, 2021

plotting and interpreting the results from the numerical exercise. We then performed simulations under the stochastic Monte-Carlo method blended with an agent-based modeling $(\mathrm{ABM})$ simulation, and the results were cross-referenced with the numerical and graphical results to strengthen the translation of the findings.

\section{The Philosophy of DOA-BOGOR}

We defined attribution in DOA as taking a slice of the economic development (i.e., preferably current GDP) indicators and examining their composition to see which were most relevant to the project/program, and assessing and understanding their outcome apportionments to the source of funding, which in this paper is ADB loans. As an illus- where: $x_{n}=$ Annual unemployment attributor; $\bar{x}$ $=$ Overall unemployment attributor; $A=A D B$ loans; $u=$ unemployment; $\bar{u}=$ mean unemployment

We get an average value (1969 to 2017) on an annual project basis of 0.127 unemployment level, over average unemployment of 4.053 , hence the ADB loans slice causes $3.13 \%$ of the unemployment in Indonesia (Appendix-B). This means ADB loans-with an average of $0.415 \%$ of GDP_are responsible for about $3 \%$ of Indonesia's unemployment. We term this as an unemployment attributor. Likewise, an equal slice of brown bread (ADB loans in a different country) will produce different results. Figure-4 below illustrates the basic mechanics of DOA-BOGOR.

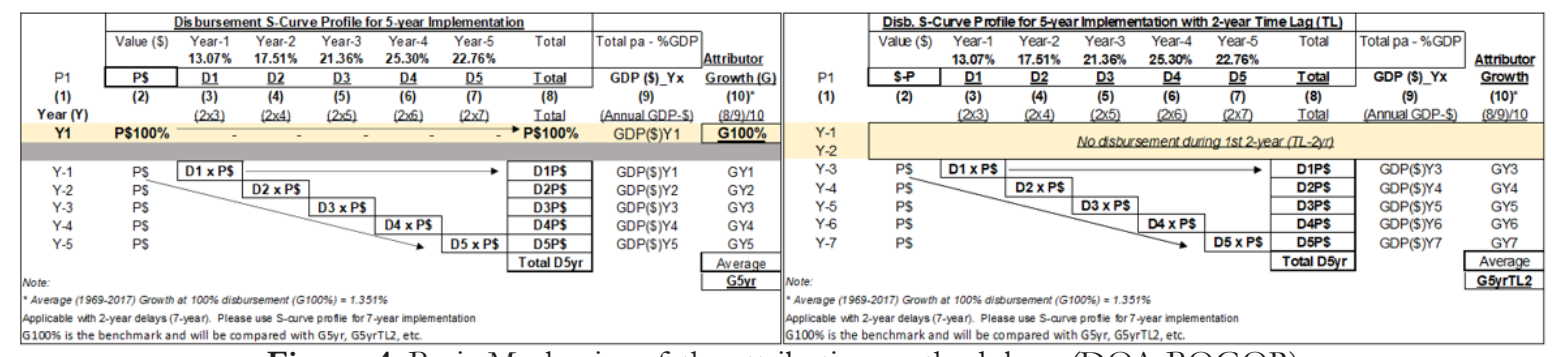

Figure-4: Basic Mechanics of the attribution methodology (DOA-BOGOR)

tration, in slices of white bread that are equally sized and weighted, one can get 3 grams of sugar, 2 grams of protein, and no fiber whilst in a slice of brown bread, it is 2 grams, 3 grams, and 2 grams respectively. Thicker or thinner slices produce different configurations. Likewise, in the GDP of Indonesia (a loaf of white bread), take a slice of the bread and that equates to the ADB loans. From the loaf, using these equations,

$$
\begin{aligned}
& x_{n}=(A / u)_{n} \\
& \bar{x}=\left(\frac{\sum_{1}^{n} f\left(x_{n}\right)}{n}\right) / \bar{u}=\left(\frac{\sum_{1}^{n}(A / u)}{n}\right) / \bar{u}
\end{aligned}
$$

\section{Description}

In this paper, we quantitatively measured unemployment as an attributor, as the ADB's loans outlay progress follows an S-curve until they reach $100 \%$ (BOGOR). The financial costs of delays (e.g., circa $30 \%$ and $250 \%$ for LF and FRB respectively) after being monetized were then endogenized as Indonesia's capital in the BOGOR. This means we benchmark the costs of delays against the $100 \%$ outlays in the first year wherein there is no delay.

Hence, we applied a 10\% bank reserve ratio as per the Central Bank of Indonesia (Bank 
Indonesia) ${ }^{12}$. We then ascribed the attribution of ADB loans as a percentage of Indonesia's $\mathrm{GDP}^{13}$ being the numerator over annual unemployment $^{14}$ equally weighted (linearized) annually (See Figure-4). From this, we get an unemployment attributor of 3.13\% (Appendix-B). Factual disbursement profiles were used to produce a normalized S-curve profile following the implementation plan with delays of 2 to 5 years (Table-1). We then spread the ADB loans over the succeeding five and seven years, according to their disbursement profiles per the actual or projected S-curve. Thus, using equations 1 and 2 and Figure-4, we derived the unemployment attributors of $2.40 \%$ (five years) and $2.17 \%$ (seven years) and compared them with $3.13 \%$ (at 100\% disbursement in the first year). We adjusted the actual interest rates, $\mathrm{LIBOR}^{15}$, and fees as per the banking rules of the $\mathrm{ADB}^{16}$ to calculate the compounded amounts from the undisbursed funds. We then monetized and endogenized them under LF and FRB adopting the stock-flow consistent (SFC) model principle of double-entry to balance the money created and its multiplication from the LA date.
$(1,250 \%)$ for LF and FRB respectively. We used them as multiplicators of the ADB loans (percentage of GDP) at 100\% disbursement in year one. From this, we get the unemployment attributors of $-4.06 \%$ (LF) and $-6.70 \%$ (FRB). Negative signs show endogenized sources. We stochastically imitated the disbursement with Monte-Carlo simulations combined with agent-based modeling (ABM) using a mean of 4.34 and a standard deviation of 2.00 for Indonesia's unemployment and their relationship with the ADB loans. We ran an unemployment attributor simulation with a minimum of 1,000 iterations using $5 \%$ disbursement increments by treating the disbursement ratio and unemployment as agents, by harnessing MS-Excel's What-if Analysis Data Table function. For estimating the future total loan principal plus interest, using an average Indonesian ADB loan interest rate of $4.727 \%$, we adopted the Rule of 70 with 19 years as the average loan life and the average ADB loans since 1969 of $0.415 \%$ of GDP. Hence $\{2 \times 0.415 \times 19 /(70 / 4.727)\}$ $=1.065 \sim 1.07 \%$ of GDP, which value is in

Table-1: Normalized ADB Disbursement S-curve Profiles (2008-2017)

\begin{tabular}{|c|c|c|c|c|c|c|c|c|c|c|}
\hline Disbursement & Year-1 & Year-2 & Year-3 & Year-4 & Year-5 & Year-6 & Year-7 & Year-8 & Year-9 & Year-10 \\
\hline Standard (5-year) & $13.07 \%$ & $17.51 \%$ & $21.36 \%$ & $25.30 \%$ & $22.76 \%$ & - & - & - & - & - \\
\hline 2-year Delay (7-year) & $7.25 \%$ & $11.69 \%$ & $15.54 \%$ & $19.48 \%$ & $16.94 \%$ & $16.03 \%$ & $13.07 \%$ & - & - & - \\
\hline 3-year Delay (8-year) & $6.08 \%$ & $10.52 \%$ & $14.38 \%$ & $18.31 \%$ & $15.78 \%$ & $14.86 \%$ & $11.90 \%$ & $8.17 \%$ & - & - \\
\hline 5-year Delay (10-year) & $5.38 \%$ & $9.83 \%$ & $13.68 \%$ & $17.62 \%$ & $15.08 \%$ & $14.17 \%$ & $11.20 \%$ & $7.47 \%$ & $3.46 \%$ & $2.12 \%$ \\
\hline
\end{tabular}

In this paper, we adopted a simplified approach ${ }^{17}$ by using $1.3(30 \%)$ and 12.5

\footnotetext{
${ }^{12}$ Undang-Undang Republik Indonesia Nomor 23

Tahun 1999 Tentang Bank Indonesia

${ }^{13}$ Current GDP in US\$

${ }^{14}$ Annual unemployment in $\%$.

${ }^{15}$ The London Inter-bank Offered Rate (LIBOR)

${ }^{16}$ ADB Operations Manual OM Section D1/BP

(Ordinary Capital Resources) https://www.adb.org/ sites/default/files/institutional-document/31483/ om-d1.pdf (Accessed 5 Jan 2021)

${ }^{17}$ Ideally, subject to the availability of actual yearly disbursement data, they should be treated as the project
}

between the $2 \%(0.45 \%$ of GDP $)$ and $5 \%$ $(1.13 \%$ of GDP) interest rates shown in Figure-11.

\section{Data}

Time-series datasets from the $\mathrm{ADB}^{18}$ covering 325 (Loan Project No. 0012 to

progresses under S-curve profiles with compounded interest and fees on undisbursed sums added.

${ }^{18}$ Source: https://data.adb.org/dataset/statement-adbs-sovereign-loans-1968-2017 (11 Dec 2020) 
3,561) of Indonesia's loans, along with over 1,100 sub-loans, from 1969 to 2017 which totaled over $\$ 33$ billion (Appendix-C), (World Bank $^{19}$, Ministry of Finance (MOF) for the Government of Indonesia (GOI), and St. Louis Fed economic database (FRED) $)^{20}$. The World Bank data provides the unemployment level (Dataset: SL.UEM.TOTL. ZS (ILO estimates)) and SL.UEM.TOTL. NE.ZS (national estimate) and the current GDP (NY.GDP.MKTP.CD). FRED data caters to various interbank lending rates. As all ADB loans are below 1\% of GDP, except for one outlier at $2.3 \%$ of GDP, coinciding with the 1998 Asian financial crisis, we kept it as is to maintain the data's integrity and to show the impact of increasing ADB loans as a percentage of GDP. We fill gaps in the data by interpolating them from their neighboring values. We provide the summary statistics in Appendix-D.

\section{Results}

\section{Findings}

Delays, despite them disadvantaging Indonesia in many areas (i.e., the economy, finance, social politics), are financially and politically beneficial for the $\mathrm{ADB}$ and its commercial banks, where the ADB deposits the undisbursed loan funds. Financially, it gains compounded interest and fees while politically, it remains in control of Indonesia's sovereign capital which is collateralized with over $\$ 8$ billion. All three approaches, as expounded below, show that the bars under $\mathrm{LF}$ and/or FRB in numerical and stochastic approaches, outsized a 100\% disbursement; while the tip of the curves under five and seven year delays in the graphical approach

\footnotetext{
${ }^{19}$ Source: World Bank Open Data https://data. worldbank.org or https://data.worldbank.org/topic/ economy-and-growth (11 Dec 2020)

${ }^{20}$ Source: https:/ / fred.stlouisfed.org (11 Dec 2020)
}

outnumbered the $100 \%$ disbursement. These tell us that ADB loans do not reduce unemployment in Indonesia, because of their disbursement delays. On the contrary, they worsen the situation. Visually, the numbers, charts, and graphs show a downtrend and uptrend as $\mathrm{ADB}$ loans (as a percentage of GDP) increase which means ADB loans initially reduce unemployment but as the loans increase so does unemployment. We have observed the same with ADB loan disbursement delays. Increased unemployment is correlated with longer disbursement delays, which translates as the longer the delays the fewer jobs the ADB's loans create.

\section{Pilot view}

To provide confidence on the stability of the data and DOA-BOGOR analysis, Figure- 5 provides the view for the pilot from which we see volatilities of $19 \%$ and $24 \%$ because of the five and seven year delays, respectively. The endogenized costs of which cause $130 \%$ and $214 \%$ volatility under LF and FRB at $17 \%{ }^{21}$ correspondingly.

The Spearman correlation test suggests a significant, moderately strong correlation of -0.33 (0.03), which means unemployment reduced by one-third as the ADB's loans increased. The trend goes in the opposite direction faster because of the five and seven year delays, with a significant strong correlation of $0.81(0.00)$ and $0.79(0.00)$ respectively with $100 \%$ disbursement in the first year. This implies that more $\mathrm{ADB}$ loans create fewer new jobs and cause more unemployment, and it worsens by $80 \%$, hence 0.47 0.5 ( 0.80 to 0.33$)$ or decays by half because of the delays. Figure- 5 shows unemployment was down from $5 \%$ to $2.8 \%$ (44\%) before

\footnotetext{
${ }^{21}$ See Bezemer and Hudson (2016) on 15\% GDP transactions that contribute to growth.
} 
Ingratubun et al

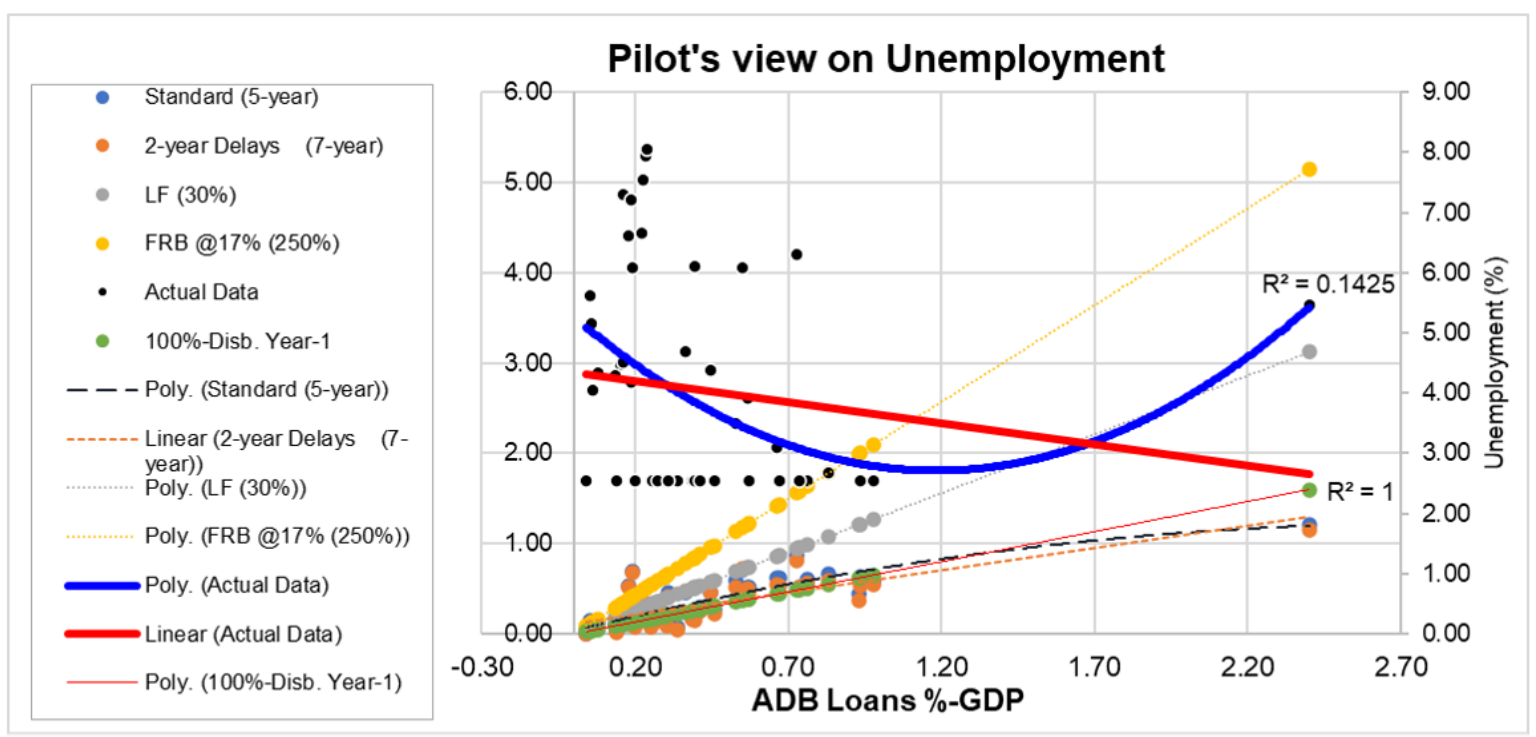

Unemployment (Source: World Bank dataset (ILO Estimate) SL.UEM.TOTL.ZS, as 5 Jan 2021)

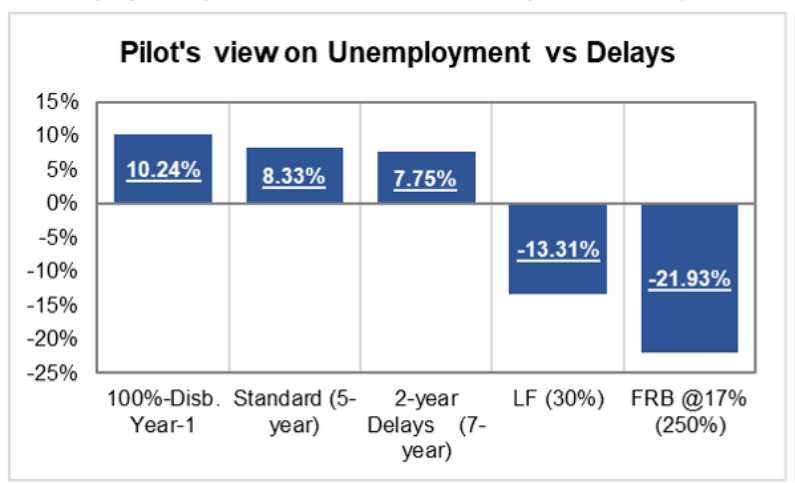

Pilot's view on Unemployment's Volatility

Note: Negative signs mean monetized and endogenized costs

Figure-5: Indonesia Unemployment vs ADB Loans Relationship

increasing to $5.5 \%(96 \%)$, hence an overall $50 \%$ increase (or job losses). This shows that overall the ADB loans have no positive impact on reducing unemployment. This has proven that Ibnu Khaldun (1377:359) was right about government intervention bringing about negative effects on social utility and being a great mistake.

Disbursement delays slow the convergence between the increase of $\mathrm{ADB}$ loans and their impact on unemployment, however, the LF and FRB speed up the intersection. We translate this as the ADB delays the disbursements, despite on the surface appearing to slow down the worsening of unemployment. In the background, the costs of those delays after being monetized and endogenized are increasing unemployment and things worsen when the ADB loans start at $1.2 \%$ of GDP at $100 \%$ disbursement in the first year. We saw the relevance of this when we triangulated the results between the three approaches. The pilot view prepared us to see the negative impact of $\mathrm{ADB}$ loans and the delay in dispersing them, which worsens unemployment.

\section{Discussion}

\section{Numerical}

Figure-6 shows that ADB loans account for $3.13 \%$ of unemployment, from the na- 
tional average of $4.053 \%$ per year, under $100 \%$ disbursement into the economy of Indonesia after signing the LA in year one. However, the decision not to disburse 100\% of the agreed loan in the first year degenerates the ADB loans slice for unemployment by about $23 \%$ (from $3.13 \%$ to $2.40 \%$ ), and hence exposes the negative impacts of disbursement delays versus 100\% disbursement.

These values are much smaller compared with those under LF (incorporating 30\% compounded interests and fees) and FRB (250\%) which pulls unemployment into $-4.06 \%$ and $-6.70 \%$ correspondingly, thus a $200 \%$ volatility (Figure-7). The R-squared value shows that

\section{Graphical}

Instead of using the World Bank's dataset with the ILO estimate (SL.UEM.TOTL. $\mathrm{ZS})$, here we used the dataset for the national estimate (SL.UEM.TOTL.NE.ZS) to reflect the confidence the GOI has, that it can reduce the unemployment level. We applied GOI's national estimate to minimize the gaps, had we used larger values such as the ILO estimate. Notwithstanding the smaller values, the STATA $^{22}$ graphical results are similar. Hence, after observing the trend in the data between linear, quadratic, and polynomial, we selected the fractional polynomial (FP) as an inter-

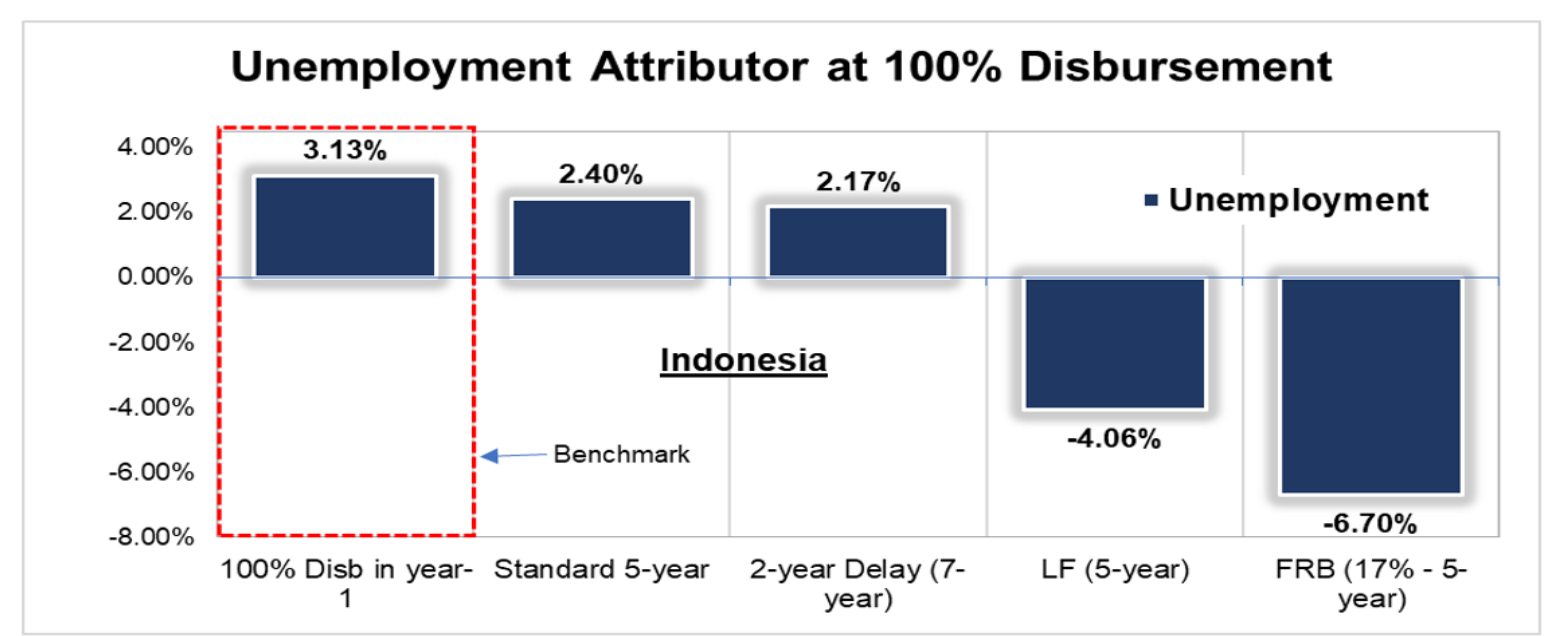

Source: Processed.

Figure-6: Unemployment attributor vs delays

a 94\% deterioration in the ADB's loan value is relevant to the employment creation potential, because of delays. This means the stability of the ADB's loans for creating jobs is less than $10 \%$. We calculated the FRB impact by considering that $15 \%$ of FRB amounts are for real GDP transactions and contribute to growth (Bezemer and Hudson, 2016). Hence, to account for transaction costs, we apply $17 \%$ because of the U.S. dollar denomination, despite it being around $30 \%$ of real GDP transactions in rupiah, after disaggregating the data from Bank Indonesia. mediate between non-linear and polynomial (Royston and Sauerbrei, 2007:27). We chose FP over a linear regression since its Bayesian information criteria (BIC) is smaller ( $\mathrm{Ta}-$ ble-2).

Figure- 8 presents the comparison between the linear and FP graphs, with and without the outlier. From this, we can see that linear regression does not capture much of the detailed information, while FP is better at getting it. Linear lines show a continuous de-

${ }^{22}$ STATA is a software for Statistics and Data Science. https://www.stata.com (27 Apr 2021) 


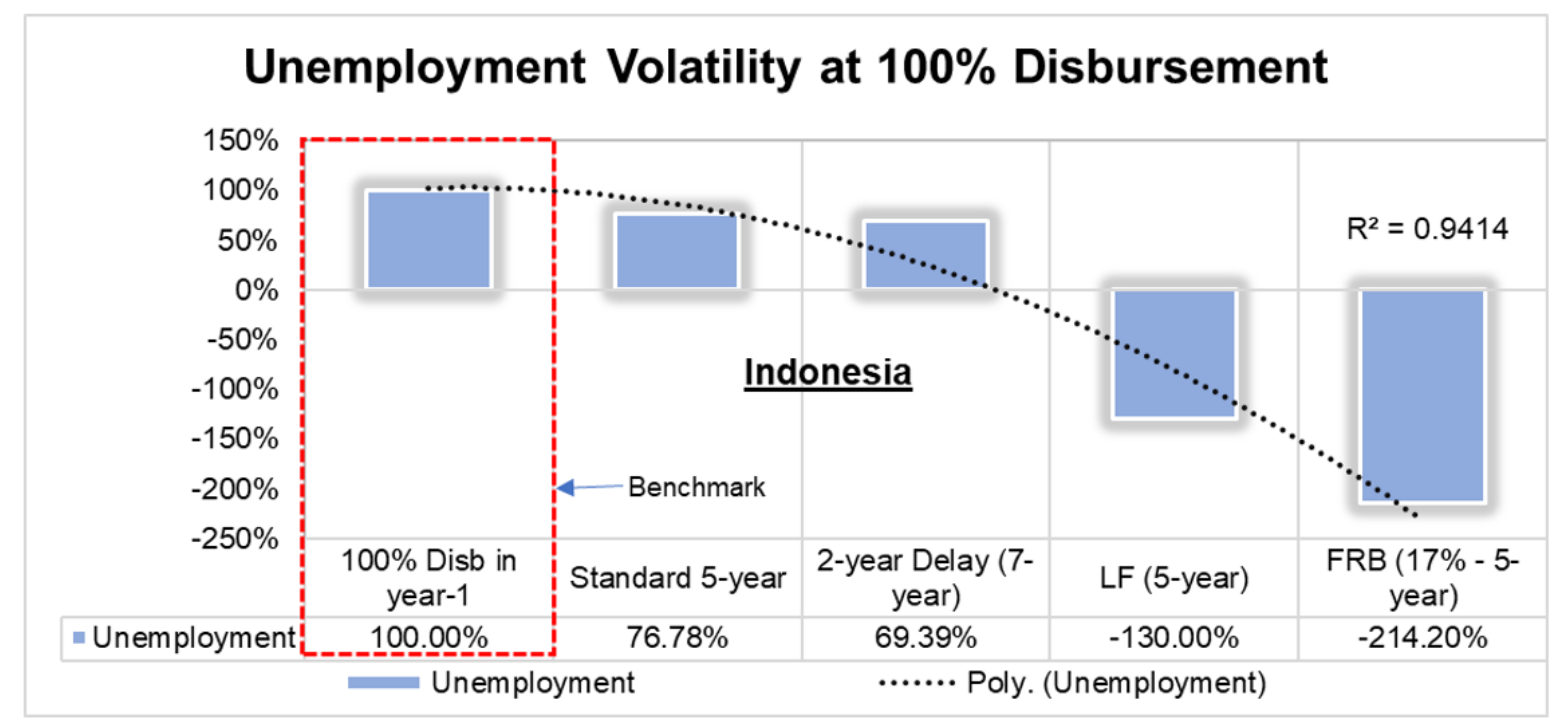

Source: Processed.

Figure-7: Unemployment attributor decays rate

crease in unemployment, corresponding with the increase in $\mathrm{ADB}$ loans (as a percentage of GDP) whereas the FP lines are closely related to the actual data.

\section{Note: Dangers of excluding outliers!}

ADB loans at 2.3\% of GDP in 1998 (financial crisis) at $100 \%$ disbursement in the first year, if treated as an outlier and thus eliminated, would give a false picture that tured by DOA-BOGOR in FP in the five and seven year disbursement, in which both show that increases in unemployment corresponded to the size of the ADB's loans and linearly correlated with the length of the delays. This means the longer the delays, the worse unemployment gets, which is a sign of ineffective investment. It is our view that when dealing with loan data, one should not exclude outliers. After all, we must account for them since they are public money.

Table-2: Bayesian information criterion (BIC)

\begin{tabular}{|c|c|c|c|c|c|c|}
\hline Model & Obs & ll(null) & $11($ model $)$ & $\mathrm{df}$ & AIC & $\mathrm{BIC}$ \\
\hline Linear-All & 43 & - 90.38 & - 81.58 & 4.00 & 171.17 & 178.21 \\
\hline FP2-100\% Diab. & 43 & - 21.49 & -14.26 & 3.00 & 34.52 & 39.80 \\
\hline FP2-5-year & 43 & $-\quad 1.87$ & - $\quad 0.92$ & 3.00 & 7.85 & 13.13 \\
\hline FP2-7-year & 43 & 0.69 & 1.67 & 3.00 & 2.67 & 7.95 \\
\hline FP2-All & 43 & -21.49 & 13.79 & 5.00 & 17.58 & $\begin{array}{l}-\quad 8.77\end{array}$ \\
\hline FP1-All & 43 & -21.49 & 4.29 & 4.00 & 0.59 & 6.45 \\
\hline
\end{tabular}

Note: Processed with STATA. Data sources are from ADB (2020) and World Bank (2020)

$F P=$ Fractional Polynomial; 1 and 2 are the maximum degree of FP being 2 is STATA's default

AIC $=$ Akaike Information Criterion

most $\mathrm{ADB}$ loans reduce unemployment (figures 8 to 11 , outlier excluded, see $100 \%$ disbursement in year one). This is false as cap-
Figure-9 displays the 95\% confidence interval with a larger confidence area as the ADB loans increase, and Figure-10 shows the 

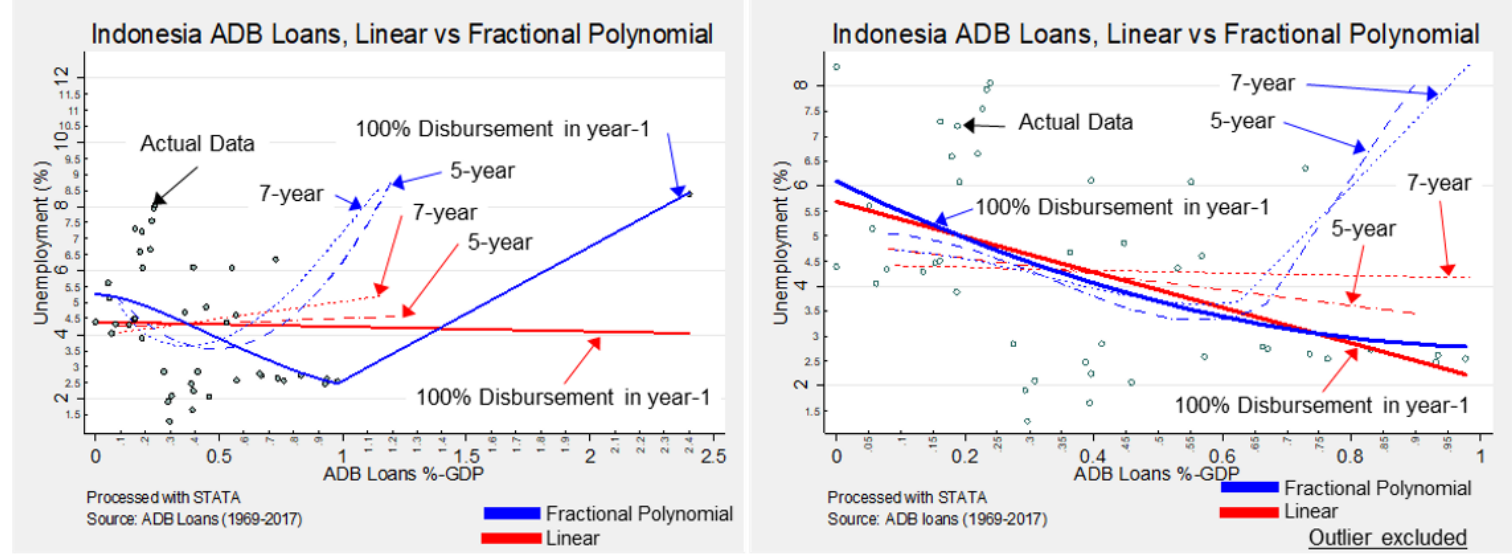

Source: World Bank dataset national estimate (SL.UEM.TOTL.NE.ZS, 2020). Processed with STATA.

Figure-8: Visual inspection of the best graphical representation of unemployment data, with and without outlier areas affected by delays and that differ from the $100 \%$ disbursement. Figure-11 exhibits the coordinates of the specific observed points. These graphs show the conditions with and without the outlier. Both show the same downward trend, followed by upward movements which means that, as ADB loans increase, unemployment is initially reduced but then increases. These were shortened

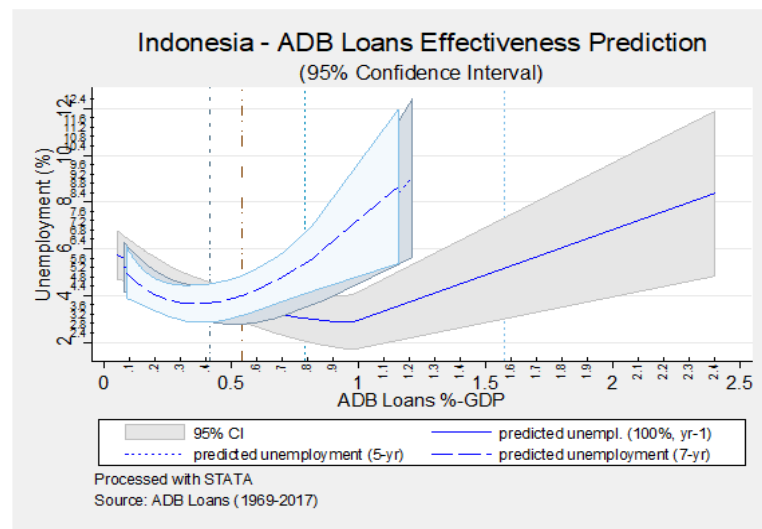
a steady one-third unemployment reduction from $5.6 \%$ to $3.6 \%$, but the effects worsened beyond $0.415 \%$ of GDP (Figure-11). In tandem with the five and seven year delays, the ADB loans, plus their annual interest rate being more than $2 \%$ per annum, signal a severe deterioration in Indonesia's unemployment rate at $0.79 \%$ of GDP as it is reversing the initial one-third gains. This means the ADB

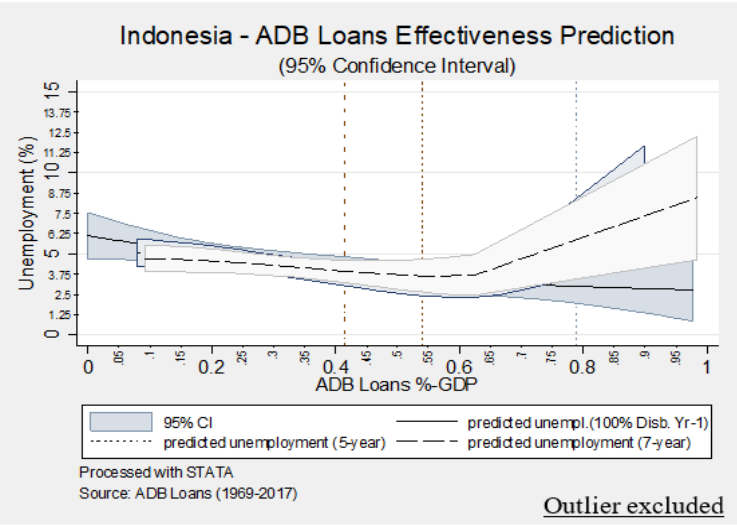

Source: World Bank dataset national estimate (SL.UEM.TOTL.NE.ZS, 2020). Processed with STATA

Figure-9: ADB's loans effectiveness with a confidence interval, with and without outlier

and then worsened by half because of the disbursement delays.

Hence, the STATA two-way graph fractional polynomial function (FPFIT) predicted that ADB loans (at $0.415 \%$ of GDP average loans to Indonesia, from 1969 to 2017), if disbursed $100 \%$ in year one, would maintain loans plus interest have no impact at all on reducing unemployment.

Despite initially reducing unemployment until the ADB loans are at $0.415 \%$ of GDP (average from 1969 to 2017), they increase it by over 1.7 times (5.01\% to $8.9 \%)$. Interestingly, even at $100 \%$ disbursement in 

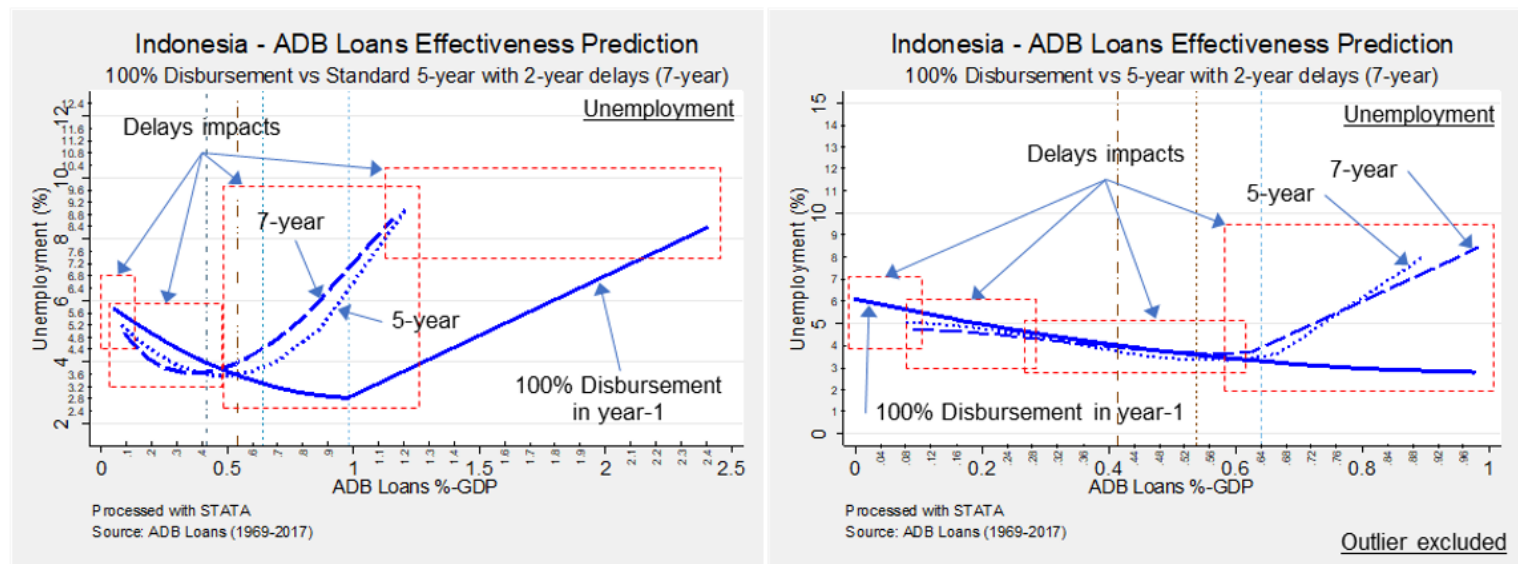

Source: World Bank dataset national estimate (SL.UEM.TOTL.NE.ZS, 2020). Processed with STATA

Figure-10: Impacts of delays on ADB loans effectiveness on Indonesia unemployment, with and without outlier

the first year under LF $(0.54 \%$ of GDP), the loan amount plus compounded interest on undisbursed amounts, causes unemployment to increase or fewer new jobs creation. Under $\mathrm{FRB}(17 \% \times 12.5 \times 0.415 \%$ of GDP $=0.9 \%$ of GDP), below the 5\% interest payments, this further aggravating unemployment. This hints that the impact of the money created under LF and/or FRB or CC not favoring Indonesia upon signing the LA, and this means the ADB's loans negatively influencing unemployment. Indonesia is better off without ADB loans for job creation or for reducing its unemployment level. Therefore, it is the cornerstone of the argument not to delay the

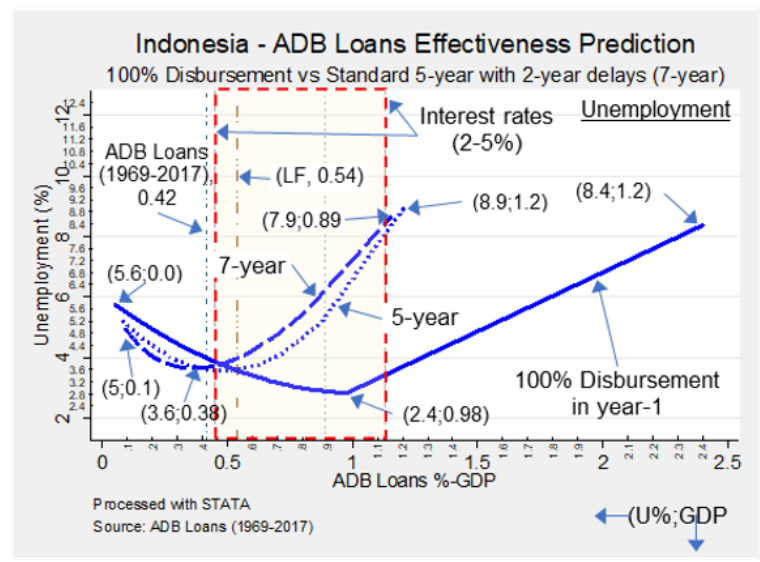

disbursement, as the development outcomes will suffer critically from the volatility of Indonesia's national economic engine.

Using the econometrics approach, Bulír and Hamann (2006); Rajan and Subramanian (2008); Doucouliagos and Paldam (2008); Quibria (2014); Dreher and Lohmann (2015) and many others have observed similar results. Collectively, our results confirm the findings that aid has a temporarily small, positive, but statistically insignificant relevance to growth and the creation of new jobs. There is also no clear and convincing evidence that more aid leads to faster growth and less unemployment. Our paper shows that increas-

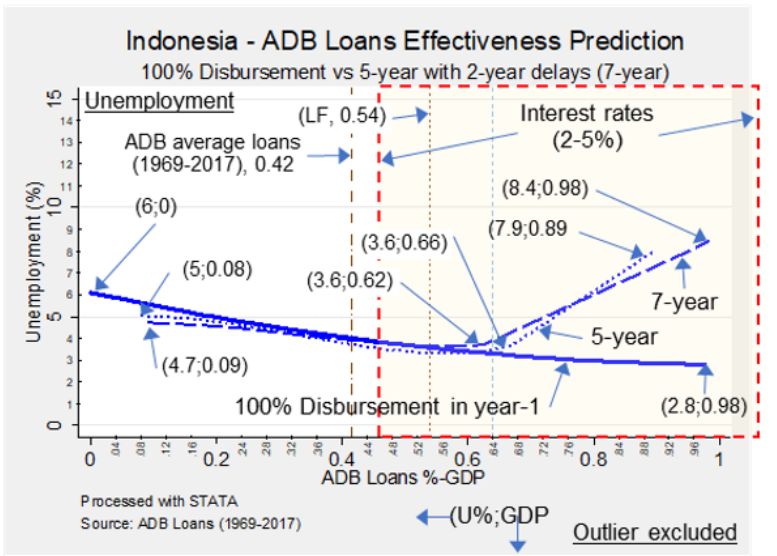

Source: World Bank dataset national estimate (SL.UEM.TOTL.NE.ZS, 2020). Processed

Figure-11: STATA's predictions with Fractional Polynomial on ADB loans effectiveness on Indonesia unemployment, with and without outlier 
Gadjah Mada International Journal of Business - May-August, Vol. 23, No. 2, 2021

ing the number of ADB loans, with their disbursement delays, plus interest, causes unemployment to triple, from $3.6 \%$ at $0.38 \%$ of GDP to $8.9 \%$ at $1.2 \%$ of GDP (five years) or $2.4 \%$ at $0.98 \%$ of GDP to $8.4 \%$ at $1.2 \%$ of GDP ( $100 \%$ disbursement) under the prevailing banking theories and practices. This ure-11 and cross-reference with Figure-12 at $75 \%$ disbursement) then in the seventh year at $70 \%$ disbursement. The Spearman correlation test $^{25}$ (Appendix-F) demonstrates that ADB loans with $100 \%$ disbursement in the first year are significant with a moderate correlation of $-0.33(0.03)$ with unemployment.
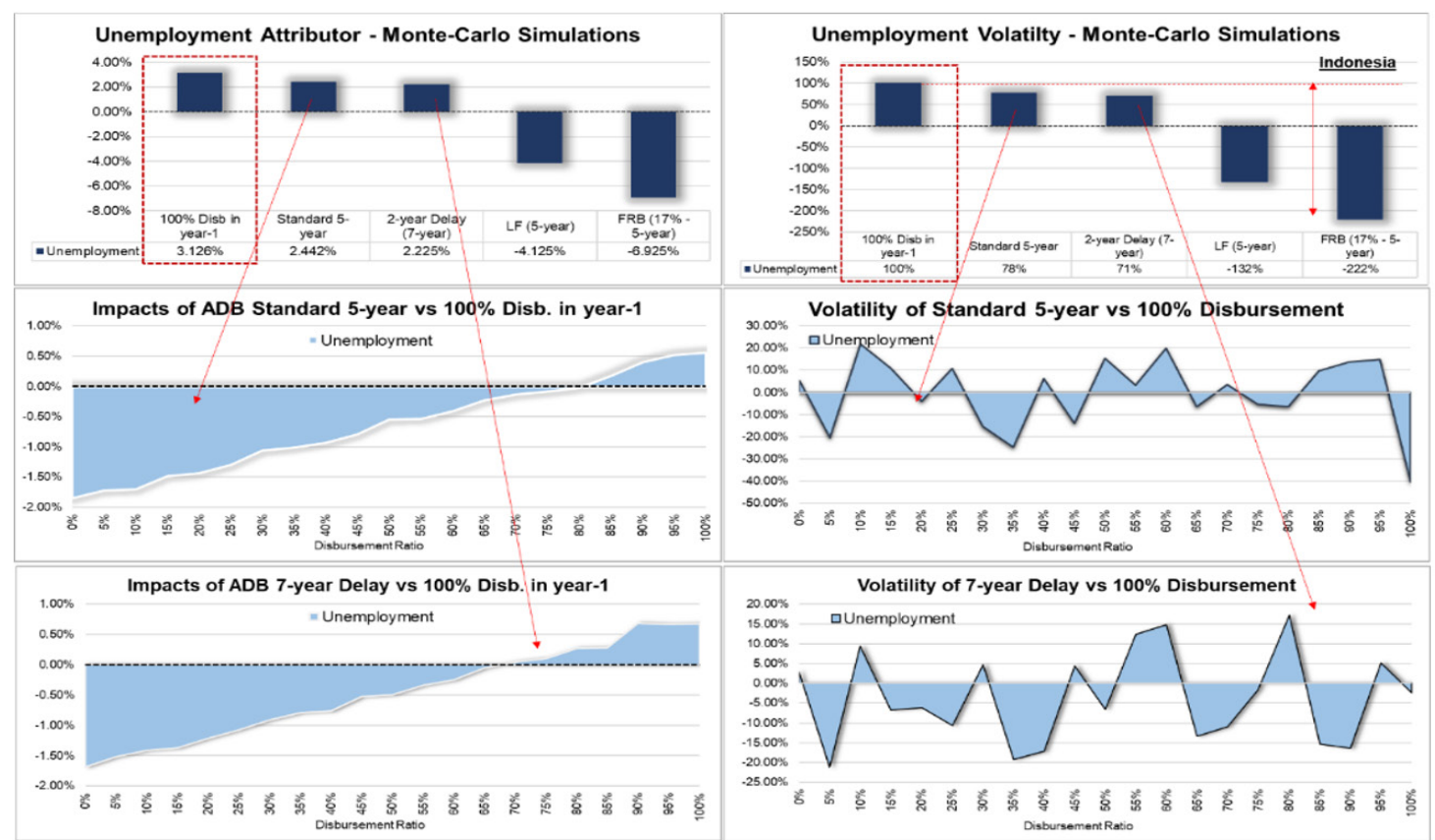

Note: Processed. Results may not be the same when rerun due to Monte-Carlo's nature. Each bar was simulated with the same percentage of disbursement increment. World Bank dataset based on ILO estimate (SL.UEM.TOTL.ZS) is used.

Figure-12: Stochastic (Monte-Carlo) agent-based simulation (SABM) results showing the impacts of delays and their volatilities, measured against $100 \%$ disbursement.

is equivalent to a ratio of (3.6/8.9):(0.38/1.2) or 1.3:1 meaning that for every $1 \%$ GDP increase in ADB loans to Indonesia, unemployment increases by $1.3 \%$.

\section{Stochastic Agent-based Modeling} (SABM)

Indonesia's unemployment is first Granger-cause by ADB loans at time-lag five $^{23}$ (TL-5) with 100\% disbursement (Appendix-E). This signals that the impact of delays are first seen in the fifth year ${ }^{24}$ (See Fig-

\section{${ }^{23}$ STATA begins with 2 instead of 1}

${ }^{24} \mathrm{This}$ is not yet incorporating money creation as a result of low time preference under LF and FRB.
On TL-1 to 4 none of them Granger-cause unemployment.

We interpreted that, as ADB loans increase, they cut down unemployment by onethird $(-0.33)$ but in the fifth year there is a significant strong correlation of $0.81(0.00)$ and in the seventh year of $0.79(0.00)$ with the $100 \%$ disbursement in the first year, hence they increase unemployment by $80 \%$. With a mean of 4.59 and a standard deviation of 2.00, we imitated the unemployment

\footnotetext{
${ }^{25}$ This test only gives a one-dimensional view of data correlation. To have a 3-dimensional perspective, this needs to be triangulated with numerical, graphical, and stochastic approaches.
} 
and $\mathrm{ADB}$ disbursement relationship under a numerical approach with Monte-Carlo simulations, with the disbursement ratios and unemployment as agents. Figure-12 shows some results. The standard deviation of two, which is about $40 \%$ of the mean value, signals Indonesia's volatile economic engine. This wider fluctuation potentially has positive and negative impacts because of the prolonged $\mathrm{ADB}$ loan disbursement time frame. From Figure-12, we observed the push-pull effects of ADB loans' impact on unemployment during the seven years the disbursement takes.

Figure-12 also shows that even without accounting for LF and FRB @17\%, owing to the ADB's standard five year implementation, this causes the potential to create new jobs in Indonesia to decrease, at around 75\% of the disbursement ratio. This is when the loans increase unemployment, compared with the $100 \%$ disbursement in the first year that continuously reduces joblessness until $1 \%$ of GDP is reached (see Figure-11).

\section{Financial impacts}

Triangulating the three results, ceteris paribus, the endogenized costs of the average two year delays engendered financial losses to Indonesia of a minimum of 1.3 to $12^{26}$ times the loan value for LF and FRB correspondingly. The ADB loans delays (actual) financial impacts per $\$ 1$ in loans, as compounded interest and fees under LF of 22.17 to $27.91 \%$ are consistent with Jepma (1991), Pallage and Robe (2001), and Kharas (2008). Whilst the FRB of $\$ 12$ (calculated) correlates with over $\$ 10$ capital flight (GFI et al., 2015) or half of $\$ 24$ (Hickel, 2017) per \$1 in aid. We estimate that only 70 to $80 \%$ of the loan amounts are actually disbursed into the economy of In-

${ }^{26}$ Under ADB's 4\% reserve ratio, yields $\$ 32$ per $\$ 1$ or 32 times of the loan value. donesia, while the ADB paid the rest to the international services providers. Das and Serieux (2015:40) approximate between 25\% to $40 \%$ of the loans do not enter the national economy. This means $5.8 \%$ to $55 \%$ (e.g. $70 \% \times 1 / 1.3$ for LF, or $1 / 12$ for FRB) of the money created, including their compounded gains, or $\$ 0.57$ (LF) to $\$ 11.5$ (FRB) per $\$ 1$ loan are capital flight and never enter the national economy.

The problem does not end here as Sogge (2017), citing Ndikumana and Boyce (2011) and van Bergeijk (2010) found that about $60 \%$ of the funds disbursed into the national economy rapidly leave the recipient country through a revolving door. The total of which is comparable with a capital flight of a minimum of $50 \%$ to $300 \%$. It correlates with our finding for Indonesia with $50 \%$ to $1,200 \%$ volatility measured against $100 \%$ disbursement in the first year. This means that Indonesia suffers from a capital flight of $4.98 \%$ of GDP, which although smaller than 7.6\% of GDP (Griffiths, 2014), is almost double the expected return of $700 \%$ (or $2.91 \%$ of GDP) per $\$ 1$ by developed member countries in their investment with the ADB (U.S. Congress, 1968a:280). It shows that the ADB's loan volatility through disbursement delays is not incidental. Acemoglu et al., (2001) attributed this to economic retardations in less developed countries (former colonies) because of the creation of extractive institutions. Hence, for Indonesia, the Dutch curse is well at work.

\section{Conclusion}

\section{Recommendations}

Given the availability of sufficient collateral, the GOI critically requires new national laws and political decisions to have any $\mathrm{ADB}$ loan funds $100 \%$ disbursed into the Indo- 
nesian banking system in Rupiah during the first year, or for Indonesia to accept no ADB loans at all. To mitigate the moral hazard ${ }^{27}$ (Coase, 1960), reforming the governance of the ADB's loan disbursements is required. This will require more studies with different attributors, endogenized capital, and LA conditions.

\section{Conclusion}

For Indonesia as a country colonized by the Dutch for 300 years, the Dutch curse, as opposed to the Dutch disease, is a fitting term to describe the capital outflow, instead of inflow, and the negative impacts on growth and unemployment because of the ADB's loan disbursement delays. Fixing this Dutch curse is simple but requires a fundamental shift, and an honest intention beyond the political narrative of reducing delays, and genuine efforts to promote growth and reduce unemployment.

"Debt is a cleverly managed re-conquest of Africa. It is a reconquest that turns each one of us into a financial slave." Thomas Sankara (1987).

\section{Limitation}

The data used is only until 2017. As more data becomes available, we will update this study.

\section{References}

Acemoglu D., S. Johnson, and J. Robinson, J., 2001. The Colonial Origins of Development: An Empirical Investigation. American Economic Review, 91(5), (Dec. 2001), pp. 1369-1401.

ADB. 2011. Urbekistan Country Assistance Program Evaluation. Evaluation Study, July 2011. Manila, Philippines: Asian Development Bank. Accessed 17 December 2020. https:/ /www.oecd. org/derec/adb/48700042.pdf

ADB. 2018. The 2018 Annual Evaluation Review. Manila, The Philippines: Asian Development Bank. Accessed 17 December 2020. https://www.adb.org/sites/default/files/evaluation-document/388366/files/2018-aer.pdf

ADB. 2019. 2018 Annual Portfolio Performance Report (APPR). Asian Development Bank. Accessed 17 December 2020. https://www.adb.org/sites/default/files/institutional-document/500841/appr-2018.pdf.

ADB. 2019. Indonesia Fact Sheet. Asian Development Bank. Accessed 17 December 2020. https:// www.adb.org/sites/default/files/publication/27769/ino-2019.pdf.

ADB. 2020. 2019 Information Statement. Asian Development Bank. Accessed 17 December 2020. https://www.adb.org/sites/default/ files/institutional-document/417506/information-statement-2020.pdf

Aldashev, G., and V. Vincenzo. 2012. Is Aid Volatility Harmful? The University of Namur. https:/ / www.tcd.ie/Economics/assets/pdf/AID_VOLATILITY_Draft_Jan8_2012_FULL.pdf 
Andrews, M., and V. Wilhelm. 2008. Thinking about Aid Predictability. NUMBER 124, PREM Notes Poverty: The World Bank.

Australian National University (ANU). 2017. Aid study shows every $\$ 1$ spent returns $\$ 7.10$ in exports. 16 October 2017. Accessed 17 December 2020. https://www.anu.edu.au/news/ all-news/aid-study-shows-every-1-spent-returns-710-in-exports

Bezemer, D., and M.J. Hudson. 2016. Finance is not the Economy: Reviving the Conceptual Distinction. Journal of Economic Issues. 50, 3, p. 745-768.

Block, W. 1988. How the Market Creates Jobs and How the Government Destroys Them (Full Edition). Accessed 17 December 2020. https://cdn.mises.org/fm588_0.pdf

Bourguignon, F., and M. Sundberg. 2007. Aid Effectiveness: Opening the Black Box. American Economic Review 97(2): 316-321.

Buliŕ, A., and J.A. Hamann. 2006. Volatility of Development Aid: From the Frying Pan into the Fire? International Monetary Fund. IMF Working Paper, WP/06/65.

Bulír, A., and T. Lane. 2004. "Aid and Fiscal Management," in Helping Countries Develop: The Role of Fiscal Policy, ed. by Gupta, S., Clements, B. and Inchauste, G. (Washington: International Monetary Fund).

Carpenter, S. B., and S. Demiralp. 2010. Money, Reserves, and the Transmission of Monetary Policy: Does the Money Multiplier Exist? Federal Reserve Board, Washington, D.C., U.S. Finance and Economics Discussion Series 2010-41.

Celasun, O., and J. Walliser. 2008. Predictability of Aid: Do Fickle Donors Undermine Aid Effectiveness? Economic Policy, 23(July), pp. 545-94.

Coase, R. 1960. The Problem of Social Cost. Journal of Law and Economics, 3(1), pp. 1-44.

Das, A., and J. Serieux. 2015, 'Aid and reverse flows: a global analysis', in the M. Arvin and B. Lew (eds) Handbook on the Economics of Foreign Aid, Cheltenham: Edward Elgar Publishing.

Desai, R. M., and H.J. Kharas. 2010. The Determinants of Aid Volatility. Working Paper 42, September 2010. Global Economy and Development.

Diarra, G.. 2011. Aid unpredictability and absorptive capacity: analyzing disbursement delays in Africa. Economics Bulletin, 31(1). pp. 1004-1017.

Doucouliagos, H., and M. Paldam. 2008. Aid effectiveness on growth: A meta-study, European Journal of Political Economy, 24(1): 1-24.

Doucouliagos, H., and M. Paldam. 2015. Finally a breakthrough? The recent rise in the size of the estimates of aid effectiveness. In the M. Arvin and B. Lew (eds) Handbook on the Economics of Foreign Aid, Cheltenham: Edward Elgar Publishing.

Dreher, A., and S. Lohmann. 2015. Aid and Growth at the Regional Level. IMF Working Paper WP/15/196. Research, Strategy, Policy, and Review Department.

Ebrahim-Zadeh, C. 2003. Dutch Disease: Too much wealth managed unwisely. Back to Basics. Finance and Development, a quarterly magazine of the IMF March 2003, Vol.40, No.1. Accessed 17 December 2020. https://www.imf.org/external/pubs/ft/fandd/2003/03/ ebra.htm

Edwards, S.. 2014. Economic development and the effectiveness of foreign aid: A historicalperspective. https:/ / voxeu.org/article/development-and-foreign-aid-historical-perspective

Eifert, B., and A. Gelb. 2005. Coping with Aid Volatility. A quarterly magazine of the IMF. September 2005, Volume 42, Number 3. Accessed 17 December 2020. https://www.imf.org/ 
Gadjah Mada International Journal of Business - May-August, Vol. 23, No. 2, 2021

external/Pubs/FT/fandd/2005/09/eifert.htm

Fauzi A. and M.A. Ingratubun. 2021. Opening the Black Box: Disbursement Delays Impacts on Growth in Asian Development Bank (ADB) Loan Projects in Indonesia. Online Conscience Conference on Social Sciences and Humanities, January 17-18, 2021. DOI: 10.5281/zenodo.4542164.

Fauzi, A.. 2019. Teknik Analisis Keberlanjutan. PT Gramedia Pustaka Utama, Jakarta, Indonesia. Galbraith, J. K. 1975. Money, Whence it Came, Where It Went. Boston, U.S.: Houghton Mifflin.

Global Financial Integrity (GFI) et al., (2015). Financial Flows and Tax Havens: Combining to Limit the Lives of Billions of People. Accessed 17 December 2020. https:/ / secureservercdn.net/45.40.149.159/34n.8bd.myftpupload.com/wp-content/uploads/2016/12/Financial_Flows-final.pdf

Gross, M., and C. Siebenbrunner. 2019. Money Creation in Fiat and Digital Currency Systems. IMF Working Paper WP/19/285. International Monetary Fund.

Hickel, J. 2017. Aid in reverse: how poor countries develop rich countries. Accessed 17 December 2020. https://www.theguardian.com/global-development-professionals-network/2017/ jan/14/aid-in-reverse-how-poor-countries-develop-rich-countries

Howarth, C. N. 2017. Does Development Aid Work? A report by Christopher N. Howarth for the Global Development Challenge. The Project for Modern Democracy. Accessed 17 December 2020. https://issuu.com/p4md/docs/pmd_aid_effectiveness_report.

Hudson, J., and P. Mosley. 2008. Aid volatility, policy, and development. World Development, 36(10), 2082-2102

Hudson, J. 2015. Consequences of Aid Volatility for Macroeconomic Management and Aid Effectiveness. World Development Vol. 69, pp. 62-74, 2015. 0305-750X/ 2014 UNU-Wider. Elsevier Ltd.

Hudson, M. J. 2018. Palatial Credit: Origins of Money and Interest. Accessed 17 December 2020. https://michael-hudson.com/2018/04/palatial-credit-origins-of-money-and-interest/

Ingratubun, M. A. 2020. (Unpublished) Tracking Effectiveness of Loan Funds (Aid) (TEA) through Development Outcomes Attribution (DOA) on Bank Outlays Growth On-development Results (BOGOR). Case Study: Indonesia Loans from the Asian Development Bank (ADB). Bogor, Indonesia.

Jepma, C. J. 1991. The tying of aid, Paris, OECD.

Kanbur, R. 2000. Aid, Conditionality, and Debt in Africa, in F. Tarp (ed.), Foreign Aid and Development: Lessons Learnt and Directions for the Future, London and New York: Routledge, 409-22.

Keen, S. 2014. Endogenous money and effective demand. Review of Keynesian Economics, 2(3), Autumn 2014, pp. 271-291. Accessed 17 December 2020. https://www.researchgate.net/ publication/271215627_Endogenous_money_and_effective_demand

Khaldun, I. 1377. The Muqaddimab: An Introduction to History. Translated by Franz Rosenthal (1969). Accessed 17 December 2020. https://asadullahali.files.wordpress.com/2012/10/ ibn_khaldun-al_muqaddimah.pdf

Kharas, H. J. 2008. Measuring the Cost of Aid Volatility. Wolfensohn Center for Development Working Papers.

Lotti, G., and A. Presbitero. 2019. The mobilization effects of multilateral development banks. Accessed 17 December 2020. https://voxeu.org/article/mobilisation-effects-multilateral-development-banks 
Mazzi, B. 2013. Treasury Finance and Development Banking. A Guide to Credit, Debt, and Risk. New Jersey, USA: John Wiley and Sons, Inc.

McKee, C., C. Blampied, I. Mitchell, and A. Rogerson. (2020). Revisiting Aid Effectiveness: A New Framework and Set of Measures for Assessing Aid "Quality". Working Paper 524, January 2020. Washington, USA: Center for Global Development.

McLeay, M., A. Radia, and R. Thomas. 2014. Money creation in the modern economy. Bank of England. Quarterly Bulletin, Q1, pp.14-27.

Minoiu, C., and S. G. Reddy. 2009. Development Aid and Economic Growth: A Positive Long-Run Relation. IMF Working Paper WP/09/118. International Monetary Fund.

Moore, B. J. 1983. Unpacking the Post Keynesian Black Box: Bank Lending and the Money Supply. Journal of Post Keynesian Economics 5(4): 537-556.

Nichols, D. M. (1994). Modern Money Mechanics. A Workbook on Bank Reserves and Deposit Expansion. 1st published in 1961. Last revision by Anne Marie L. Gonczy (1992). Chicago, IL, U.S.: Federal Reserve Bank of Chicago.

OECD, 2003, Harmonising Donor Practices for Effective Aid Delivery. DAC Guidelines and Reference Series (Paris: Organisation for Economic Co-operation and Development, Development Assistance Committee). Accessed 17 December 2020. http://www.oecd.org/dataoecd/0/48/20896122.pdf

Pallage, S. P., and M. A. Robe. 2001. Foreign aid and business cycles. Review of International Economics 9, 641-672.

Quibria, M. G. 2014. Aid effectiveness: research, policy, and unresolved issues. Development Studies Research: An Open Access Journal, 1(1): 75-87.

Rajan, R. G., and Arvind Subramanian. 2008. Aid and Growth: What Does the Cross-Country Evidence Show? Review of Economics and Statistics, 90(4): 643-665.

Royston, P., and W. Sauerbrei. 2007. The Use of Fractional Polynomials in Multivariable Regression Modelling. Presentation: Heidelberg, Germany. Accessed 17 December 2020.: http://www.biometrie.uni-heidelberg.de/statmeth-ag/veranstaltungen/magdeburg07/talks/sauerbrei. pdf

Rustiadi, E., S. Saefulhakim, and D. R. Panuju. 2018. Perencanaan Dan Pengembangan Wilayah. Jakarta, Indonesia: Yayasan Pustaka Obor Indonesia.

Shorto, R. 2013. Amsterdam: A History of the World's Most Liberal City. Doubleday

Sogge, D. 2017. Foreign Aid: Inconvenient Truths. Sinergias - diálogos educativos para a transformação social, junho 2017, No.5.

The Fed. 2020. Reserve Requirements. The U.S. Federal Reserve. Accessed 17 December 2020. https://www.federalreserve.gov/monetarypolicy/reservereq.htm

United Nations (UN). 2012. Macroeconomic stability, inclusive growth, and employment. Thematic Think Piece. ILO, UNCTAD, UNDESA, WTO. UN System Task Team on the post-2015 UN development agenda.

U.S. Congress. 1968a and 1968b. Appropriation for 1969. House of Representatives. 9th Congress, Second Session, Part 1 (94-105), pp.264-324 and Part 2 (94-955)-Economic Assistance, pp.25-39.

Werner, R. A. 2014. Can banks individually create money out of nothing? The theories and empirical evidence. International Review of Financial Analysis, 36, pp.1-19 
Gadjah Mada International Journal of Business - May-August, Vol. 23, No. 2, 2021

Werner, R. A. 2016. A lost century in economics: Three theories of banking and the conclusive evidence. International Review of Financial Analysis, 46, pp.361-379.

Witular, R. A. 2016. Asian Development Bank to reform project delivery, cut delays. The Jakarta Post (Fri, May 6, 2016). Accessed 17 December 2020. https://www.thejakartapost.com/ news/2016/05/06/asian-development-bank-to-reform-project-delivery-cut-delays.html.

Zezza, G. 2011. Godley and Graziani: Stock-Flow-Consistent Monetary Circuits. Levy Economics Institute. 